\title{
DÜBLIN
}

Technological University Dublin

ARROW@TU Dublin

2006-01-01

\section{Geographic Variation of Solar Water Heater Performance in Europe}

\author{
Y. Yohanis \\ University of Ulster \\ O. Popel \\ Academy of Sciences Russia \\ S. Frid
}

See next page for additional authors

Follow this and additional works at: https://arrow.tudublin.ie/dubenart

Part of the Mechanical Engineering Commons

\section{Recommended Citation}

Yohanis, Y., Popel, O., Frid, S.\& Norton, B. (2006). Geographic Variation of Solar Water Heater Performance in Europe.Proceedings of the Institution of Mechanical Engineers, Part A, Journal of Power and Energy vol.220, pp.395-407. doi:10.1243/095765006X76018

This Article is brought to you for free and open access by the Dublin Energy Lab at ARROW@TU Dublin. It has been accepted for inclusion in Articles by an authorized administrator of ARROW@TU Dublin. For more information, please contact arrow.admin@tudublin.ie, aisling.coyne@tudublin.ie,gerard.connolly@tudublin.ie.

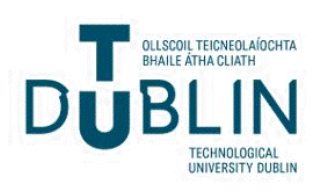


Authors

Y. Yohanis, O. Popel, S. Frid, and Brian Norton

This article is available at ARROW@TU Dublin: https://arrow.tudublin.ie/dubenart/27 


\title{
Geographic variation of solar water heater performance in Europe
}

\author{
Y G Yohanis ${ }^{1 *}$, O Popel $^{2}$, S E Frid ${ }^{2}$, and B Norton ${ }^{3}$ \\ ${ }^{1}$ Thermal Systems Engineering Group, Faculty of Engineering, University of Ulster, Northern Ireland, UK \\ ${ }^{2}$ Institute for High Temperatures (IVTAN), Russian Academy of Sciences, Moscow, Russia \\ ${ }^{3}$ Dublin Institute of Technology, Dublin, Ireland
}

The manuscript was received on 5 March 2005 and was accepted after revision for publication on 11 October 2005.

DOI: $10.1243 / 095765006 X 76018$

\begin{abstract}
Solar water heater (SWH) performance has been analysed using the 'number of days' method for 147 different sites in all European countries. The total number of days that the temperature of delivered solar heated water reaches or exceeds specified demand temperatures is correlated with solar radiation on a horizontal surface for summer, warm half-year, and whole year periods. Maps are presented and discussed showing the contours for the number of days that an illustrative SWH met different hot water demand temperatures. Correlations between number of days water is provided at a specified temperature and solar fractions for the same periods are determined.
\end{abstract}

Keywords: solar water heating, solar water heaters, geographic variations

\section{INTRODUCTION}

Although an established technology, solar water heating is still undergoing significant research and development [1]. This has been devoted increasingly to the reduction of initial installed capital cost. In the European Union, there is a substantial and growing solar water heating market [2], though its uneven development as can be seen from Table 1 reflects the relative effectiveness of market stimulation interventions. These may be aided by long-term performance characterization techniques understandable readily by consumers.

Solar water heater (SWH) design and longterm performance characterization methods have been categorized as [3, 4]: (a) utilizability based; (b) empirical correlations; (c) simplified analysis; and (d) 1-day repetitive simulations. Common to all such techniques is determination of a solar savings fraction. Yohanis et al. [5] proposed a method for SWH long-term performance characterization in which the number of days in each month (or in any given period of a year) when the temperature

*Corresponding author: Thermal Systems Engineering Group, Faculty of Engineering, University of Ulster, BT37 OQB Northern Ireland, UK. of solar heated water in SWH storage tank reaches or exceeds a specified demand temperatures is calculated. In addition to the 'solar savings fraction' [6], this 'number of days' method provides easily understood alternative SWH performance information for a potential SWH user's particular location, thus simplifying consumer decision-making. In this paper, the 'number of days' method is applied for performance analysis of solar water heating systems across Europe and empirical correlations and geographic variations derived.

\section{SOLAR WATER HEATING SYSTEM SPECIFICATION}

A pumped circulation SWH consisting of a flat-plate solar collector, a thermally insulated hot water storage tank and connecting pipes is considered as shown in Fig. 1. The circulation pump is actuated by a differential temperature controller, which interrupts water circulation in the system when the water temperature at the outlet from the collector falls below a specified value. Appropriate dead bands for temperature differences between inlet and outlet of solar collector are assumed to prevent unnecessary switching on and off of the pump. Water mass 
Table 1 Installed solar water collector areas in Europe

\begin{tabular}{lc}
\hline Country & $\begin{array}{c}\text { Installed collector area } \\
\text { per } 1000 \text { population }\left(\mathrm{m}^{2}\right)\end{array}$ \\
\hline Austria & 288.89 \\
Greece & 283.43 \\
Denmark & 60.63 \\
Germany & 45.13 \\
Switzerland & 36.11 \\
Portugal & 25.00 \\
Sweden & 25.00 \\
Netherlands & 13.48 \\
Spain & 11.42 \\
France & 9.90 \\
Finland & 5.87 \\
Italy & 5.45 \\
United Kingdom & 3.49 \\
Belgium & 2.35 \\
Ireland & 0.87 \\
\hline
\end{tabular}

flowrate in the loop is assumed to be large enough $\left(50 \mathrm{kgm}^{-2} \mathrm{~h}^{-1}\right.$ or higher) to provide a solar collector flow factor $\left(\mathrm{F}^{\prime \prime}\right)$ approaching 1 . The dependence of the solar collector heat removal factor, $F_{\mathrm{R}}$, on flowrate at this or a higher flowrate is thus negligible [7].

The following points are assumed.

1. An auxiliary heater is installed in series rather than within the storage tank to provide supplementary heating if the temperature of water withdrawn from the storage tank is below that required.

2. Each day's consumption of hot water follows the same pattern and takes place in the evenings (for the base case, total daily hot water consumption is assumed to be equal to the storage tank volume). Daily distributed water consumption compared with only nighttime consumption results in higher solar fractions due to higher solar collector efficiencies arising from lower

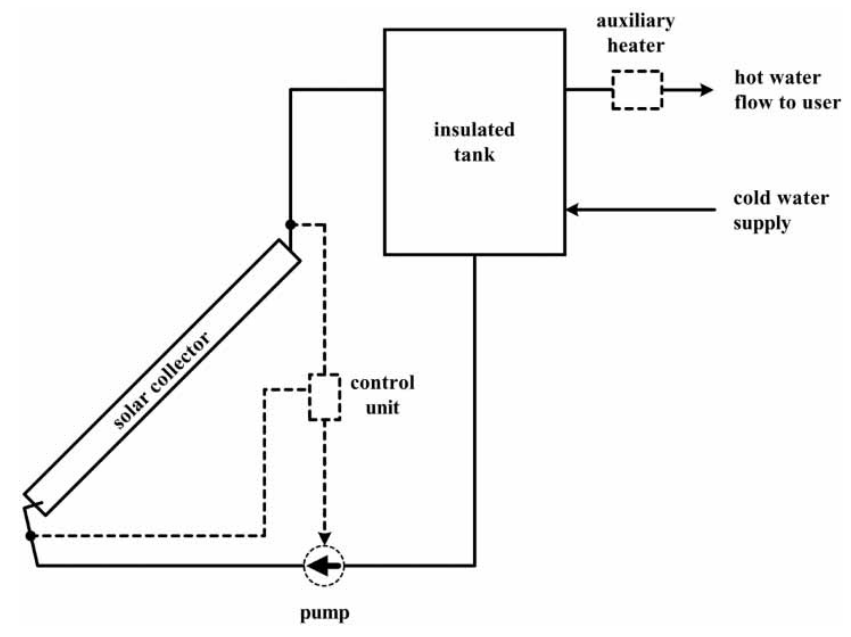

Fig. 1 A pumped circulation solar water heating system collector inlet temperatures fed from a store replenished with cold water during the day. Assuming evening water consumption therefore delineates a lower limit to the achievable provision of solar hot water that will be exceeded by most other daily hot water consumption profiles.

3. The storage tank and all connecting pipes are well insulated thermally.

4. Because the storage tank and connecting pipes are assumed to be well insulated, simultaneous proportional changing of total solar heated water consumption volume $V_{\text {day }}$, store volume $V_{\text {st }}$, and collector area $A_{\mathrm{sc}} \mathrm{SWH}$ system operation are assumed to give equivalent thermal performance.

5. The water in the storage tank is well mixed thermally, that is, there is no temperature stratification of the water inside the tank. A stratified tank, as would be likely to ensue in reality, would provide a higher draw-off temperature. Assuming a well mixed tank thus determines a lower bound to actual performance.

6. The solar collector is assumed to be single glazed, non-selective, and installed facing due south at an inclination to the horizon equal to each local latitude. The system parameters used are given in Table 2.

The solar collector area was varied in the range of 1-4 $\mathrm{m}^{2}$. Demand temperatures of 37,45 , and $55^{\circ} \mathrm{C}$ are considered. TRNSYS [8] was used to generate the hourly meteorological data in the form of typical meteorological years (TMY) for each site considered using the online 'RETScreen' database [9] to provide average monthly climatic data for each site. The uncertainty of TMY generation has been discussed in reference $[\mathbf{7}, \mathbf{8}]$. The number of days $(N)$ in each month of the year when the water temperature in the storage tank reaches or exceeds the specified demand temperature was determined by hour-by-hour simulation carried out using TRNSYS [8]. SWH simulations were carried out for the 147 European sites listed in Table 3.

Table 2 System parameters for the base case

\begin{tabular}{ll}
\hline Parameter & Value \\
\hline Solar collector area $\left(A_{\mathrm{sc}}\right)$ & $2 \mathrm{~m}^{2}$ \\
Daily hot water consumption $\left(V_{\text {day }}\right)$ & 1001 day $^{-2}$ \\
Storage tank volume $\left(V_{\mathrm{st}}\right)$ & 1001 \\
Mass flowrate & $501 \mathrm{~m}^{-2} \mathrm{~h}^{-1}$ \\
Collector slope angle $(\theta)$ & Local latitude \\
Collector thermal losses & $7 \mathrm{~W} \mathrm{~m}^{-2} \mathrm{~K}^{-1}$ \\
coefficient $\left(F_{\mathrm{R}} U_{\mathrm{L}}\right)$ & \\
Collector optical efficiency $F(\tau \alpha)$ & 0.8 \\
Initial temperature $\left(t_{0}\right)^{\mathrm{a}}$ & $10{ }^{\circ} \mathrm{C}$ \\
Mode of hot water consumption & Nighttime consumption \\
Storage tank & Well-mixed, well-insulated \\
\hline anitial daily water temperature in storage tank for all days of the \\
year.
\end{tabular}


Table 3 Total solar radiation on a horizontal surface for different times of the year and for different locations in Europe

\begin{tabular}{|c|c|c|c|c|c|c|}
\hline Location & $\begin{array}{l}\text { Latitude } \\
\left({ }^{\circ} \mathrm{N}\right)\end{array}$ & $\begin{array}{l}\text { Longitude } \\
\left({ }^{\circ} \mathrm{E}\right)\end{array}$ & $\begin{array}{l}\text { Altitude } \\
\text { (m) }\end{array}$ & $\begin{array}{l}\text { Total annual } \\
\text { solar radiation } \\
\text { on horizontal } \\
\text { surface } \\
\left(\mathrm{kW} \mathrm{h} \mathrm{m}{ }^{-2}\right)\end{array}$ & $\begin{array}{l}\text { Total solar } \\
\text { radiation on } \\
\text { horizontal surface } \\
\text { from April to } \\
\text { September } \\
\left(\mathrm{kW} \mathrm{h} \mathrm{m} \mathrm{m}^{-2}\right)\end{array}$ & $\begin{array}{l}\text { Total solar } \\
\text { radiation on } \\
\text { horizontal surface } \\
\text { from June to } \\
\text { August } \\
\left(\mathrm{kW} \mathrm{h} \mathrm{m}{ }^{-2}\right)\end{array}$ \\
\hline Aberporth (UK) & 52 & -5 & 1 & 1045 & 814 & 450 \\
\hline Alghero (Italy) & 41 & 8 & 0 & 1628 & 1155 & 647 \\
\hline Amendola (Italy) & 42 & 16 & 91 & 1540 & 1083 & 596 \\
\hline Ancona (Italy) & 44 & 14 & 1 & 1383 & 1020 & 570 \\
\hline Athinai (Athens, Greece) & 38 & 24 & 154 & 1582 & 1109 & 610 \\
\hline Badajoz/Talavera (Spain) & 39 & -7 & 168 & 1604 & 1125 & 633 \\
\hline Banja Luka (Bosnia Hercegovina) & 45 & 17 & 162 & 1277 & 937 & 522 \\
\hline Barcelona (Spain) & 41 & 2 & 1 & 1371 & 927 & 511 \\
\hline Bari (Italy) & 41 & 17 & 0 & 1586 & 1124 & 610 \\
\hline Beograd (Serbia) & 45 & 20 & 59 & 1395 & 1003 & 553 \\
\hline Bitola (Macedonia) & 41 & 21 & 583 & 1603 & 1125 & 626 \\
\hline Bologna (Italy) & 45 & 11 & 102 & 1289 & 943 & 528 \\
\hline Bolzano (Italy) & 46 & 11 & 1002 & 1231 & 885 & 483 \\
\hline Boulogne Sur Seine (France) & 51 & 2 & 30 & 1203 & 911 & 495 \\
\hline Braganca (Portugal) & 42 & -7 & 582 & 1730 & 1247 & 708 \\
\hline Bratislava (Slovakia) & 48 & 17 & 132 & 1190 & 918 & 505 \\
\hline Bremen (Germany) & 53 & 9 & 3 & 945 & 741 & 403 \\
\hline Brest (France) & 48 & -4 & 76 & 1139 & 842 & 467 \\
\hline Brindisi (Italy) & 41 & 18 & 16 & 1602 & 1136 & 637 \\
\hline Brussels-Uccle (Belgium) & 51 & 4 & 77 & 971 & 754 & 419 \\
\hline Bucuresti (Romania) & 45 & 26 & 71 & 1421 & 1041 & 577 \\
\hline Budapest (Hungary) & 47 & 19 & 103 & 1209 & 914 & 512 \\
\hline Burgos (Spain) & 42 & -4 & 861 & 1381 & 989 & 555 \\
\hline Cagliari/Elmas (Italy) & 39 & 9 & 22 & 1591 & 1101 & 618 \\
\hline Ciudad Real (Spain) & 39 & -4 & 630 & 1616 & 1111 & 615 \\
\hline Cluj/Napoca (Romania) & 47 & 24 & 354 & 1307 & 960 & 537 \\
\hline Coimbra (Portugal) & 40 & -8 & 46 & 1619 & 1090 & 597 \\
\hline Constanta (Romania) & 44 & 29 & 1 & 1427 & 1050 & 588 \\
\hline Crotone (Italy) & 39 & 17 & 1 & 1639 & 1137 & 625 \\
\hline De Bilt (Netherlands) & 52 & 5 & 3 & 991 & 774 & 434 \\
\hline Debrecen (Hungary) & 47 & 22 & 122 & 1194 & 897 & 499 \\
\hline Den Helder/De Koog (Netherlands) & 53 & 5 & 1 & 1086 & 856 & 479 \\
\hline Dijon (France) & 47 & 5 & 236 & 1309 & 973 & 546 \\
\hline Eskdalemuir (UK) & 55 & -3 & 237 & 835 & 659 & 372 \\
\hline Evora (Portugal) & 39 & -8 & 202 & 1840 & 1292 & 723 \\
\hline Faro (Portugal) & 37 & -8 & 1 & 1805 & 1238 & 677 \\
\hline Florence (Italy) & 44 & 11 & 91 & 1304 & 995 & 568 \\
\hline Funchal (Madeira) & 33 & -17 & 0 & 1739 & 1101 & 573 \\
\hline Galati (Romania) & 46 & 28 & 2 & 1441 & 1046 & 582 \\
\hline Gdansk (Poland) & 54 & 19 & 15 & 1076 & 857 & 483 \\
\hline Geisenheim (Germany) & 50 & 8 & 84 & 1037 & 808 & 448 \\
\hline Gela (Italy) & 37 & 14 & 0 & 1784 & 1202 & 653 \\
\hline Genova/Sestri (Italy) & 44 & 9 & 68 & 1151 & 829 & 464 \\
\hline Graz University (Austria) & 47 & 15 & 355 & 1127 & 820 & 451 \\
\hline Groningen/Eelde (Netherlands) & 53 & 7 & 3 & 1015 & 801 & 454 \\
\hline Hamburg-Sasel/Fuhlsbuttel (Germany) & 54 & 10 & 31 & 978 & 783 & 447 \\
\hline Helsinki/Ilmala (Finland) & 60 & 25 & 26 & 994 & 850 & 509 \\
\hline Hohenpeissenberg (Germany) & 48 & 11 & 798 & 1213 & 856 & 465 \\
\hline Iasi (Romania) & 47 & 28 & 77 & 1323 & 982 & 550 \\
\hline Jokioinen (Finland) & 61 & 24 & 114 & 947 & 809 & 480 \\
\hline Karlstad (Sweden) & 59 & 13 & 41 & 1048 & 880 & 521 \\
\hline Kassel (Germany) & 51 & 9 & 155 & 981 & 764 & 419 \\
\hline Kaunas (Lithuania) & 55 & 24 & 94 & 890 & 707 & 407 \\
\hline Kiev (Ukraine) & 50 & 31 & 169 & 1060 & 825 & 483 \\
\hline Klagenfurt-Flughafen (Austria) & 47 & 14 & 431 & 1254 & 915 & 500 \\
\hline Kolobrzeg (Poland) & 54 & 16 & 49 & 1091 & 892 & 517 \\
\hline Kopaonik (Serbia) & 43 & 21 & 1394 & 1349 & 907 & 517 \\
\hline La Coruna (Spain) & 43 & -8 & 0 & 1166 & 768 & 416 \\
\hline Lerwick (UK) & 60 & -1 & 0 & 788 & 659 & 377 \\
\hline Lille (France) & 51 & 3 & 25 & 1088 & 818 & 453 \\
\hline
\end{tabular}


Table 3 Continued

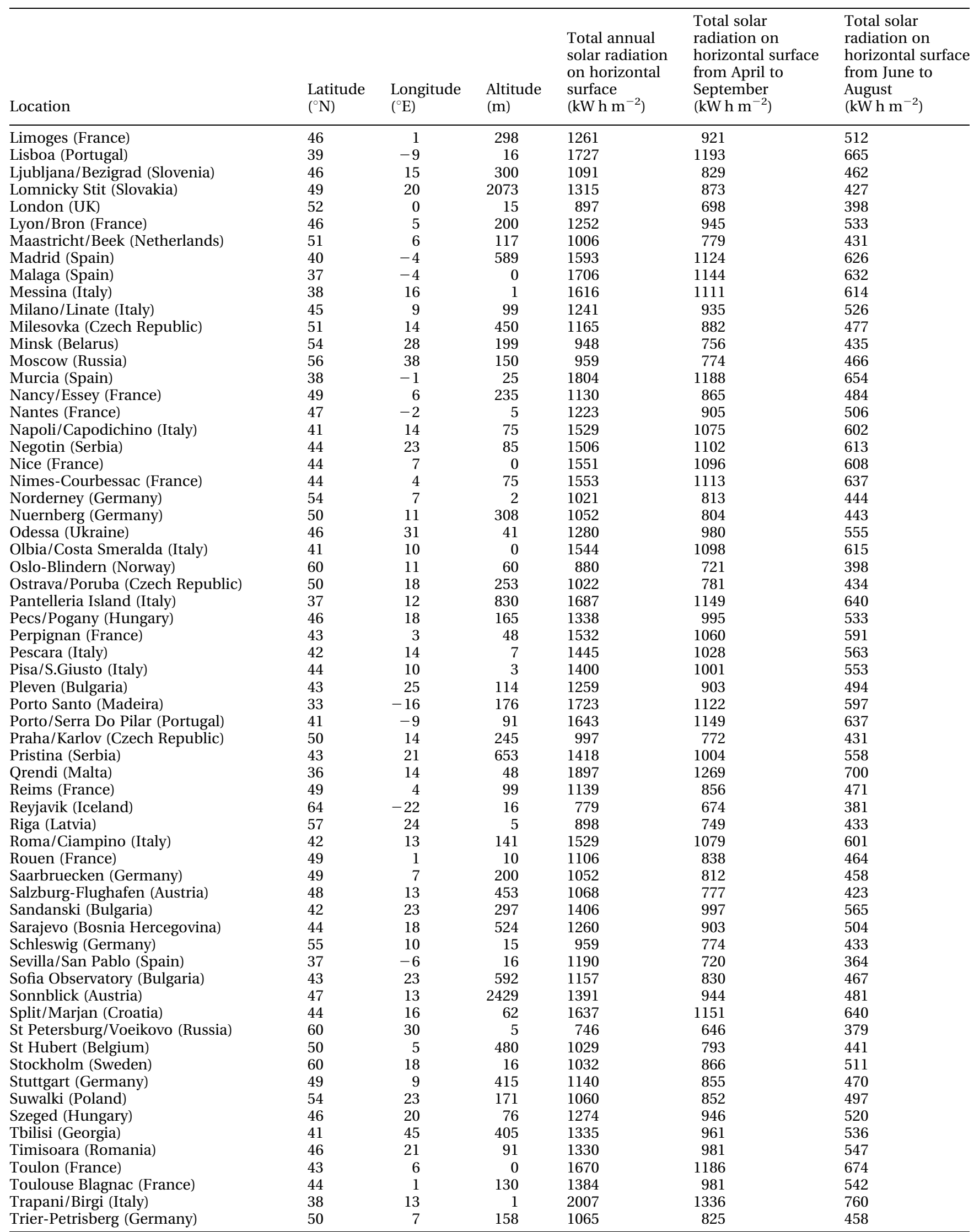


Table 3 Continued

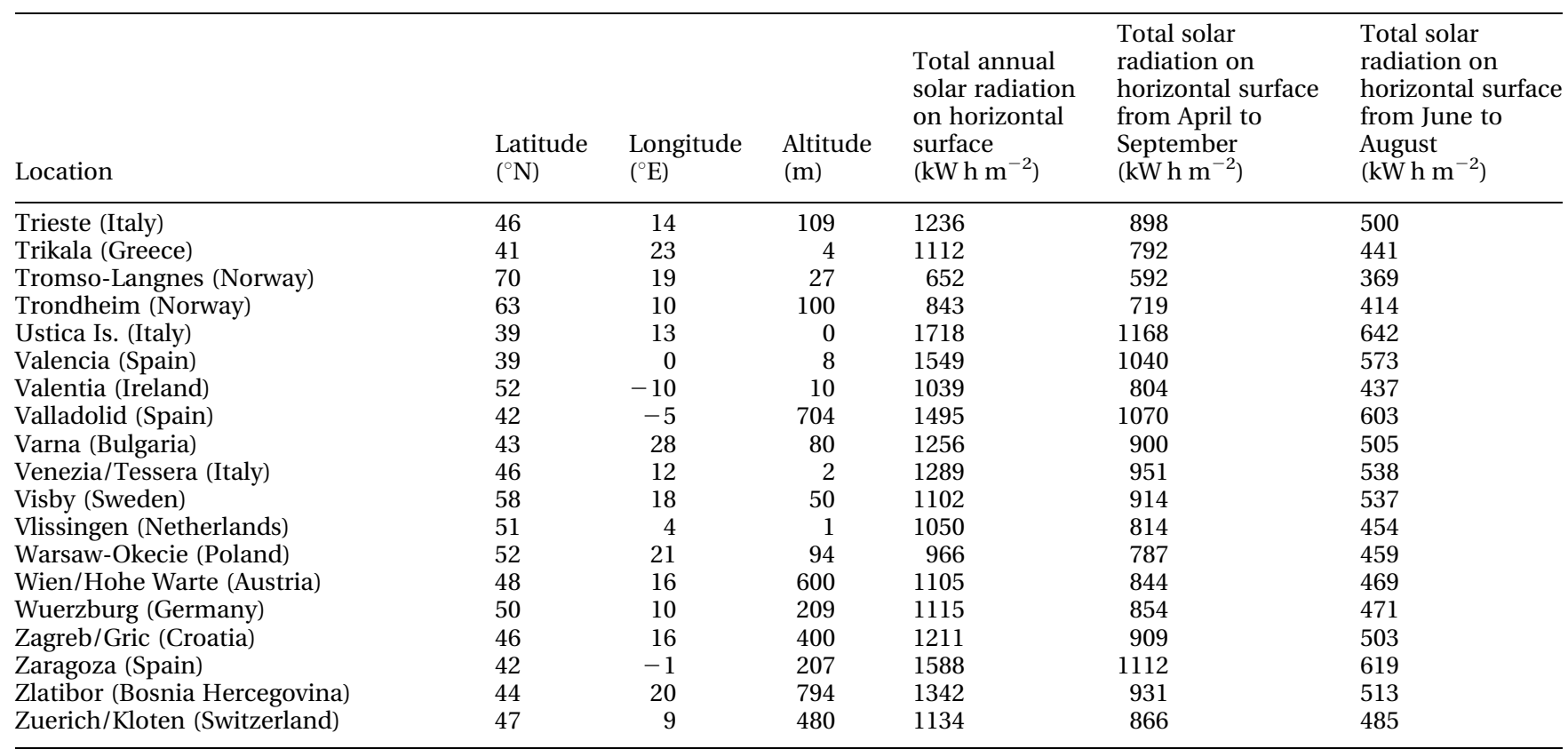

\section{RESULTS}

The number of days that the temperature of water in the storage tank reaches or exceeds specified demand temperatures as a function of total solar radiation and collector surface area for different time periods is shown in Figs 2 to 4 for the whole year, Figs 5 to 7 for the warm half-year period (i.e. April to September), and Figs 8 to 10 for summer (i.e. June to August). Each figure shows results for demand temperatures of 37,45 , and $55^{\circ} \mathrm{C}$. In

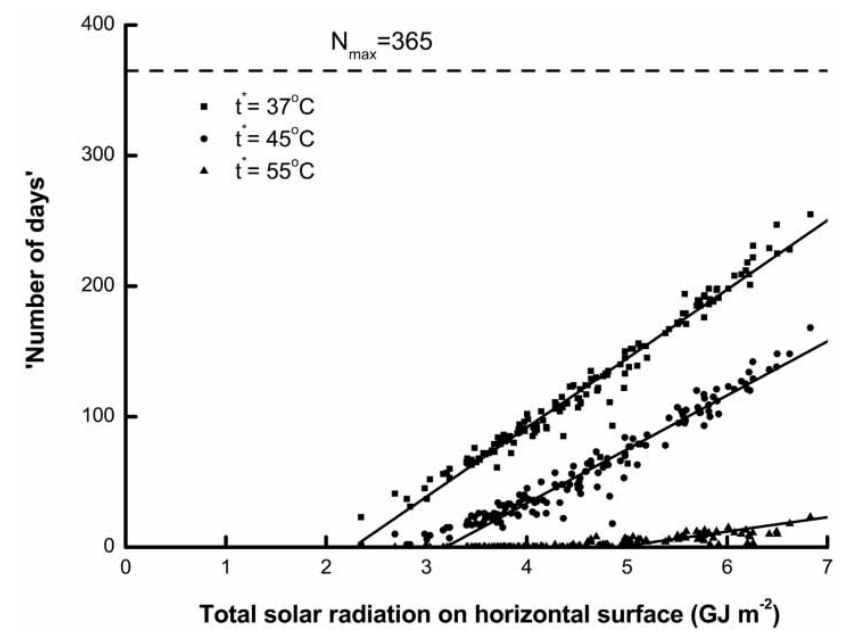

Fig. 2 The number of days for which the temperature of water in the storage tank reaches or exceeds specified demand temperatures as a function of daily total solar radiation on horizontal surface for a collector area of $1 \mathrm{~m}^{2}$ and for the whole year continental Europe, monthly average solar heated water temperatures are broadly lower for higher latitudes. Figs 2 to 10 show that there is a clear dependence of the 'number of days' on total solar radiation for all three time-periods considered (i.e. whole year, warm half-year, and summer) and at all three demand temperatures considered (i.e. 37, 45, and $55^{\circ} \mathrm{C}$ ). Significant deviation from general trends may be seen for results corresponding to Lomnicky Stit (Slovakia), Sonnblick (Austria), and Kopaonik (Serbia). These high altitude locations

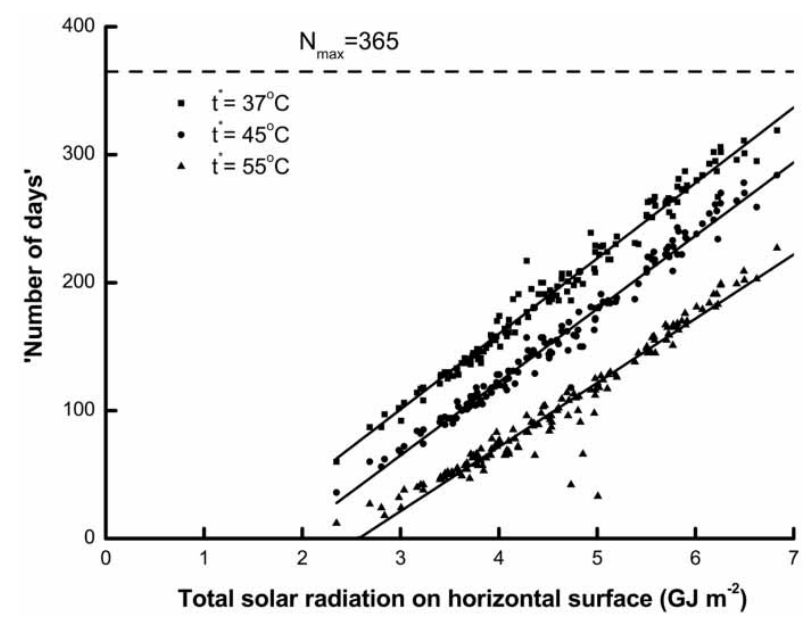

Fig. 3 The number of days for which the temperature of water in the storage tank reaches or exceeds specified demand temperatures as a function of daily total solar radiation on horizontal surface for a collector area of $2 \mathrm{~m}^{2}$ and for the whole year 


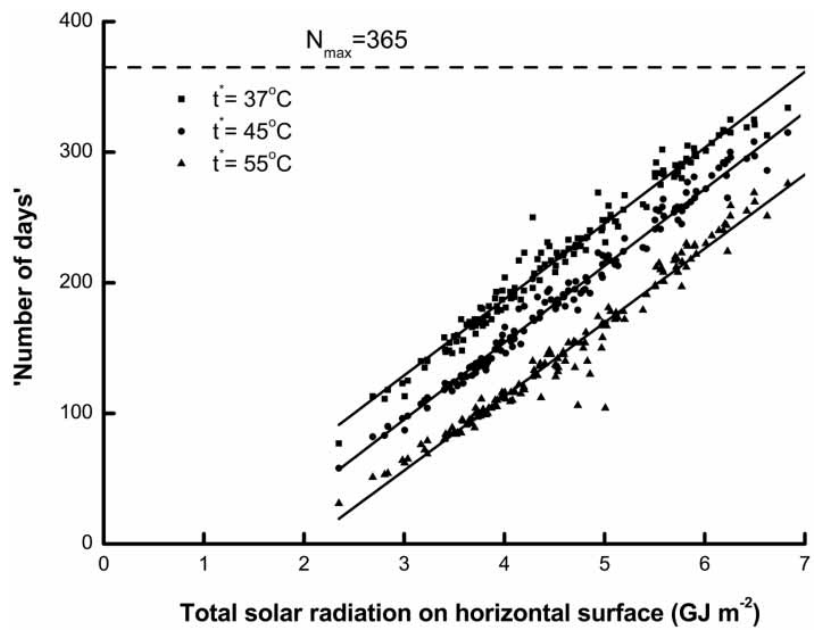

Fig. 4 The number of days for which the temperature of water in the storage tank reaches or exceeds specified demand temperatures as a function of daily total solar radiation on horizontal surface for a collector area of $3 \mathrm{~m}^{2}$ and for the whole year

combine high solar radiation with relatively lowambient temperatures. For these locations, the relative dispersion of data increases with increasing total solar radiation. This is because in mountainous areas, there are wide differences in ambient temperature (the principal determinant of heat loss from the collector) for similar levels of insolation. Contour maps of the variation of 'number of days' are shown in Figs 11 to 13 for demand temperatures of 37,45 , and $55^{\circ} \mathrm{C}$, respectively.

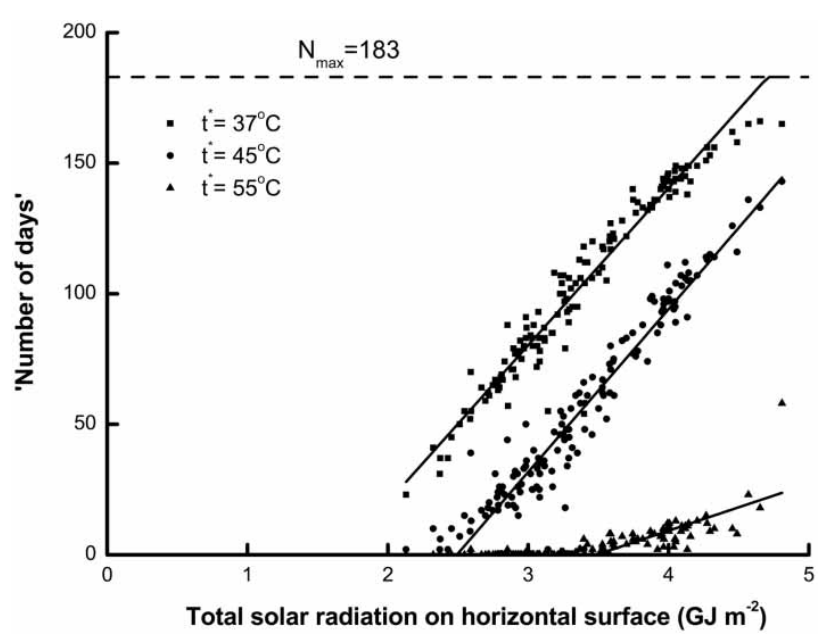

Fig. 5 The number of days for which the temperature of water in the storage tank reaches or exceeds specified demand temperatures as a function of daily total solar radiation on horizontal surface for a collector area of $1 \mathrm{~m}^{2}$ and for the period April to September

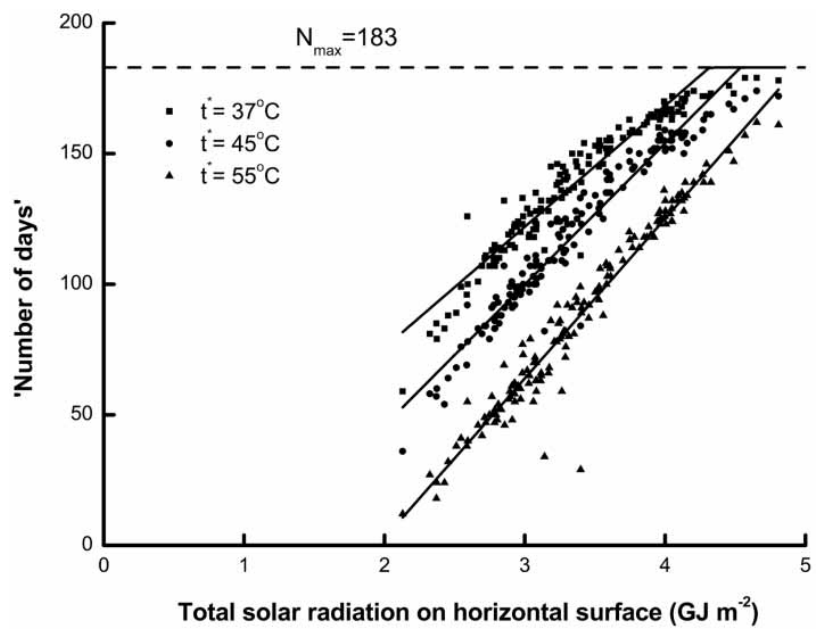

Fig. 6 The number of days for which the temperature of water in the storage tank reaches or exceeds specified demand temperatures as a function of daily total solar radiation on horizontal surface for a collector area of $2 \mathrm{~m}^{2}$ and for the period April to September

\section{CORRELATION OF TYPICAL SWH PERFORMANCE}

For a specified demand temperature, the number of days that specified hot water demand temperature could be satisfied, $N$, may be assumed to depend solely on the total insolation for the period of year considered. For a particular demand temperature, demand profile and system specification, $N$, may then be determined for any location solely as a

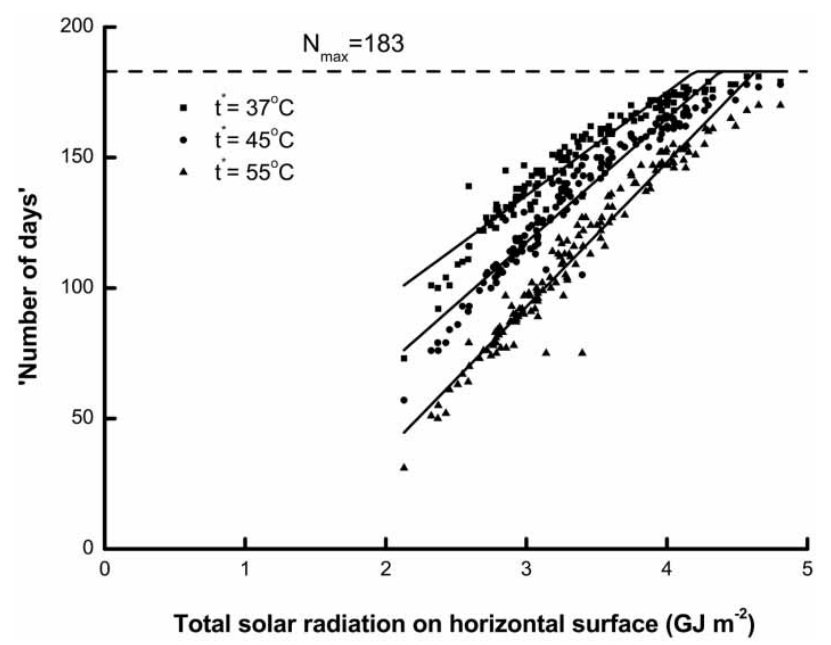

Fig. 7 The number of days for which the temperature of water in the storage tank reaches or exceeds specified demand temperatures as a function of daily total solar radiation on horizontal surface for a collector area of $3 \mathrm{~m}^{2}$ and for the period April to September 


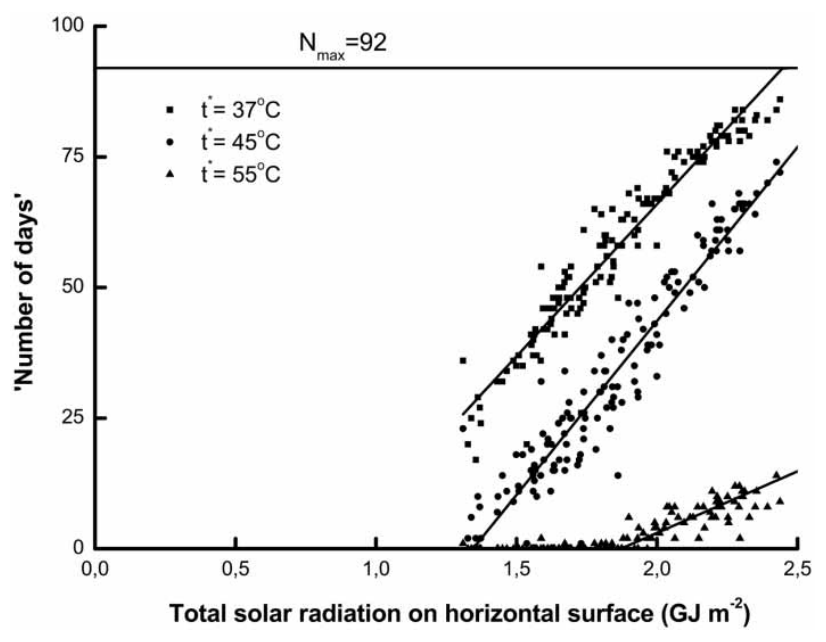

Fig. 8 The number of days for which the temperature of water in the storage tank reaches or exceeds specified demand temperatures as a function of daily total solar radiation on horizontal surface for a collector area of $1 \mathrm{~m}^{2}$ and for the period June to August

function of total insolation. A correlation between number of days and total solar radiation has the form

$$
N= \begin{cases}0 & \text { for } I<I_{0} \\ \frac{\left(I-I_{0}\right)}{\left(I_{\max }-I_{0}\right)} N_{\max } & \text { for } I_{0} \leqslant I \leqslant I_{\max } \\ N_{\max } & \text { for } I>I_{\max }\end{cases}
$$

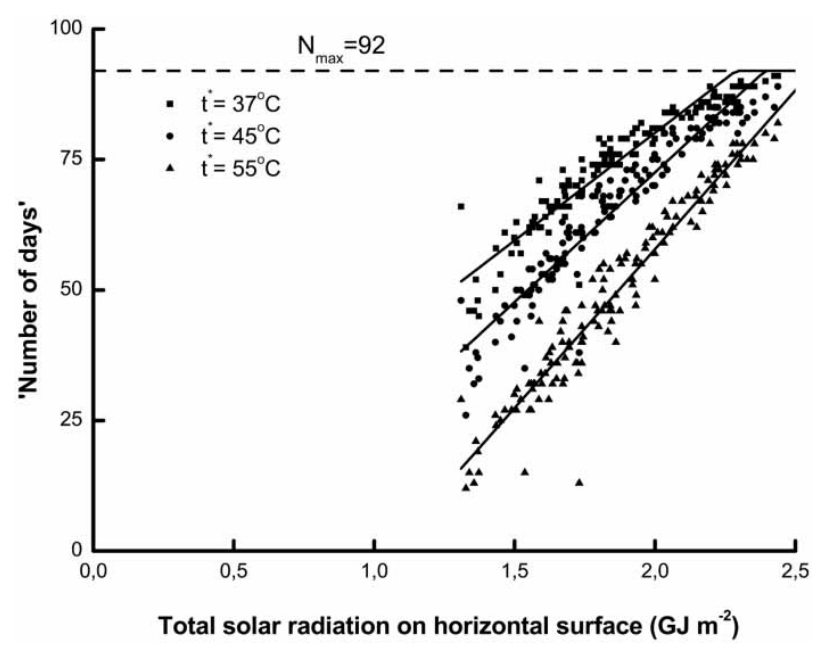

Fig. 9 The number of days for which the temperature of water in the storage tank reaches or exceeds specified demand temperatures as a function of daily total solar radiation on horizontal surface for a collector area of $2 \mathrm{~m}^{2}$ and for the period June to August

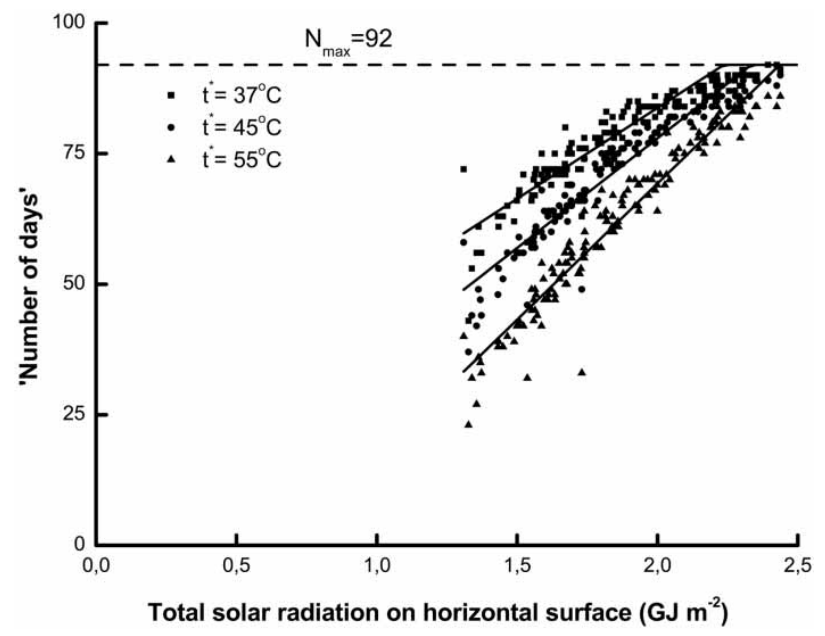

Fig. 10 The number of days for which the temperature of water in the storage tank reaches or exceeds specified demand temperatures as a function of daily total solar radiation on horizontal surface for a collector area of $3 \mathrm{~m}^{2}$ and for the period June to August

For summer, $N_{\max }=92$ days; for April to September, $N_{\text {max }}=183$ days; and for the whole year, $N_{\max }=365$ days. If the total solar radiation is less than a minimum threshold value of total solar radiation on horizontal surface, $I_{0}$, then the SWH will be unable to heat water to the specific demand temperature. The minimum threshold insolation increases with increase in specific demand temperature and decreases with increasing solar collector area per unit store volume. The number of days during which the solar heated water temperature exceeds the specified demand temperature is limited to the total number of days in the period under consideration. When the total number of days is reached, the water temperature in SWH storage tank will obviously exceed the specific demand temperature for every day within the period. The latter is associated with a maximum threshold value of insolation, $I_{\max } I_{0}$ and $I_{\max }$ depend on the solar collector area and the duration of the period under consideration with relationships of the form

$$
\begin{aligned}
I_{\mathrm{o}} & =a \cdot \exp \left(\frac{b}{A_{\mathrm{sc}}}\right) \\
I_{\max } & =c \cdot \exp \left(\frac{d}{A_{\mathrm{sc}}}\right)
\end{aligned}
$$

Coefficients ' $a$ ', ' $b$ ', ' $c$ ', and ' $d$ ' have been obtained from calculations using the least-squares method; the values of these coefficients are given in Table 4 are only valid for collector areas in the 


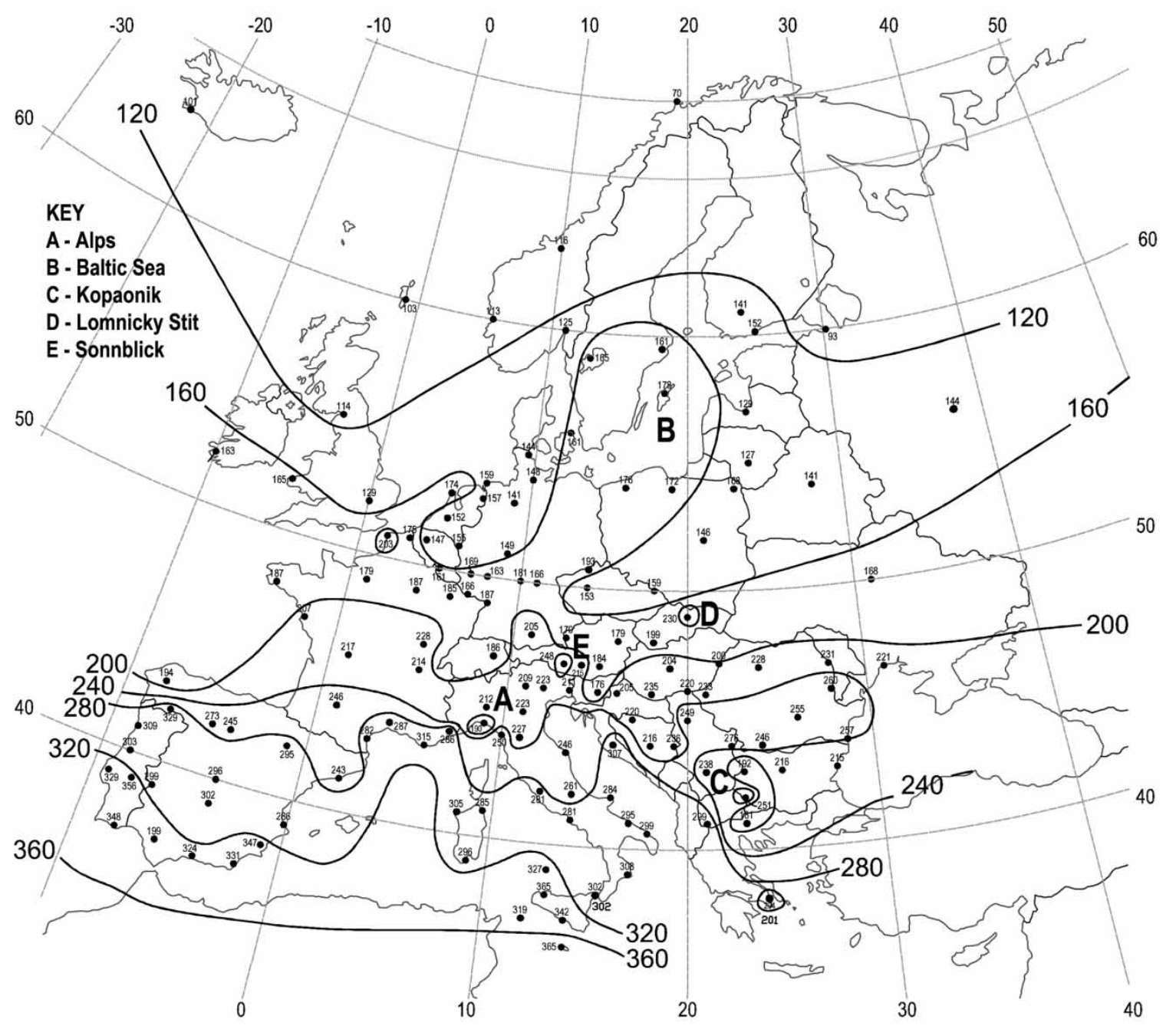

Fig. 11 Contour maps of the number of days in a year for which the temperature of water in the storage tank reaches or exceeds $37^{\circ} \mathrm{C}$ for Europe

range $1-4 \mathrm{~m}^{2}$ and total solar radiation on horizontal surface in the range $1.08-2.16 \mathrm{GJ} \mathrm{m}^{2}$ for summer, $1.8-3.6 \mathrm{GJ} \mathrm{m}^{-2}$ for the warm half-year, and 2.52$5.4 \mathrm{GJ} \mathrm{m}^{-2}$ when the whole year is considered. The inaccuracy in determining the number of days for which a specified demand temperature is satisfied arising from using equations (1) and (2) is in the range $10-30$ per cent due to the approximation error; the error is the smallest for high values of total solar radiation.

\section{SENSITIVITY OF SWH PERFORMANCE TO SOLAR COLLECTOR PARAMETERS}

Many solar collectors have one transparent cover and do not have a selective coating $[\mathbf{1 0}, \mathbf{1 1}]$. Their overall heat loss coefficient $\left(U_{\mathrm{L}}\right)$ varies in the range $5.5-7.0 \mathrm{~W} \mathrm{~m}^{-2} \mathrm{~K}^{-1}$ and their optical coefficient $(\tau \alpha)$ varies in the range $0.78-0.8$. As the range of $\tau \alpha$ is small, sensitivity analysis has been carried out only for $U_{\mathrm{L}}$. As $A_{\mathrm{sc}}$ increases, $N$ depends more on insolation and the influence of $U_{\mathrm{L}}$ on $N$ is reduced. Data dispersion depends mainly on geographical location of sites; the other parameters are the periods of year, specific demand temperature, and $A_{\mathrm{sc}}$ considered. Considering this dispersion as random, the influence of $U_{\mathrm{L}}$ can be estimated [12] for the European locations considered

$$
\begin{aligned}
\left\langle\frac{N_{U_{\mathrm{L}}}=5}{N_{U_{\mathrm{L}}}=7}\right\rangle & =1.13 \pm 0.008 ; \\
\left\langle\frac{N_{U_{\mathrm{L}}}=9}{N_{U_{\mathrm{L}}}=7}\right\rangle & =0.86 \pm 0.008
\end{aligned}
$$

where brackets denote averaging for all variants. Thus, $U_{\mathrm{L}}$ changing from 7 to $5 \mathrm{~W} \mathrm{~m}^{-2} \mathrm{~K}^{-1}$ increases 


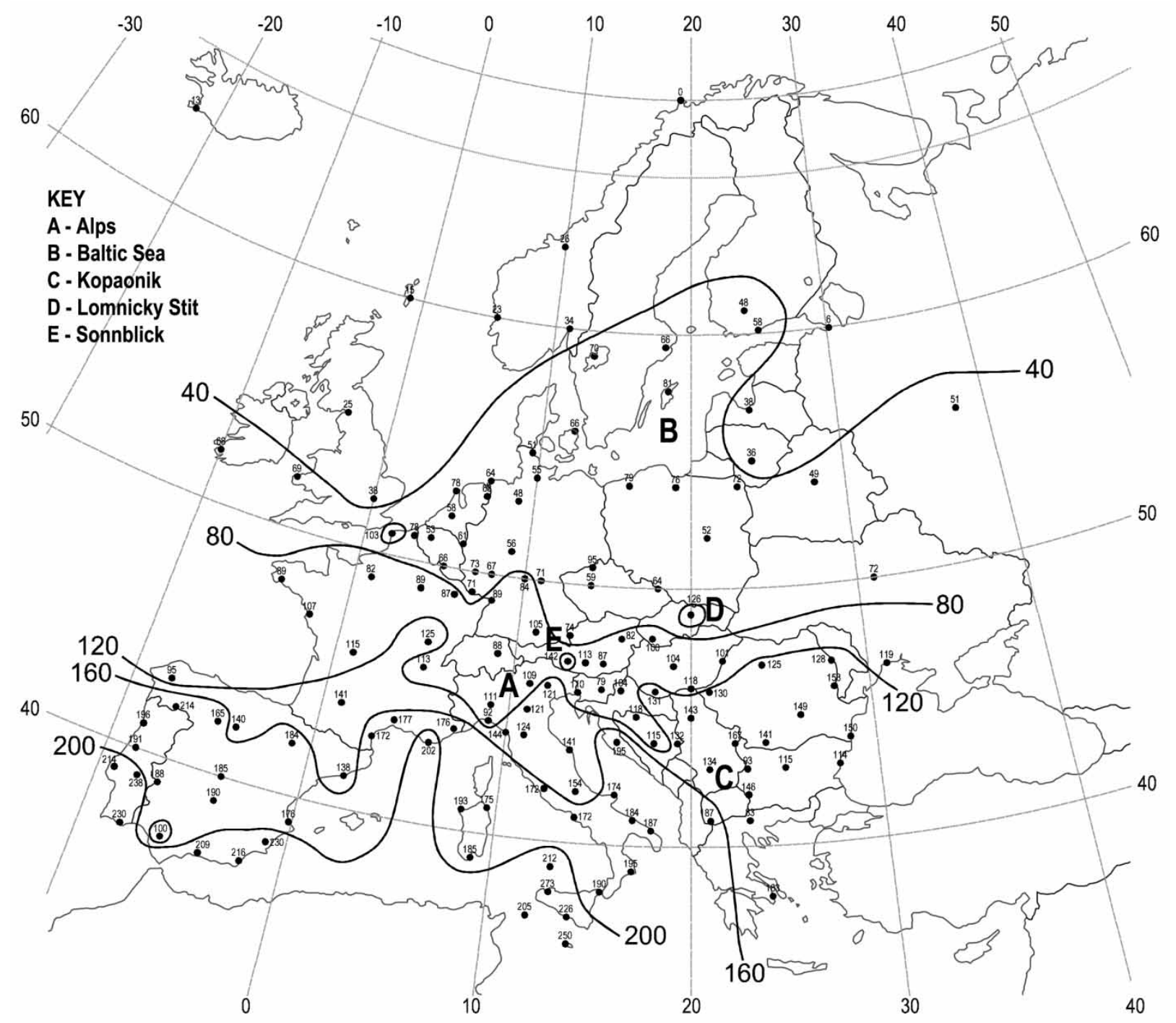

Fig. 12 Contour maps of the number of days in a year for which the temperature of water in the storage tank reaches or exceeds $45^{\circ} \mathrm{C}$ for Europe

$N$ by 13 per cent and increasing of $U_{\mathrm{L}}$ from 7 to $9 \mathrm{~W} \mathrm{~m}^{-2} \mathrm{~K}^{-1}$ decreases this value by 14 per cent.

\section{CORRELATION BETWEEN 'NUMBER OF DAYS' AND 'SOLAR A FRACTION'}

The results of calculation of 'number of days' and 'solar fractions' for SWH with storage tank volume of $100 \mathrm{l}$ and daily water consumption of $1001 \mathrm{day}^{-1}$ for two periods of SWH operation (whole year and April to September) and all considered sites in Europe are shown in Fig. 14. For both cases, the solar collector surface area was varied in range of 1-4 $\mathrm{m}^{2}$; the specified demand temperatures were 37,45 , and $55^{\circ} \mathrm{C}$. The solar fraction for each day is calculated as shown below, where the initial temperature of the water in the storage tank is $10^{\circ} \mathrm{C}$.

$$
f=1-\frac{Q_{\mathrm{aux}}}{Q_{\mathrm{tot}}}
$$

If solar preheated water temperature to the end of a day was equal to or higher than the demand temperature, the solar fraction was considered as equal to 1. Average solar fraction for both considered periods of year was calculated as the ratio of the sum of daily solar fractions to the amount of days in the period. $N$ was normalized to the amount of days in each period too.

All correlation data points were plotted on a graph of normalized 'number of days' versus average solar fraction for considered periods of year as shown in Fig. 14. The lower the normalized number of days, 


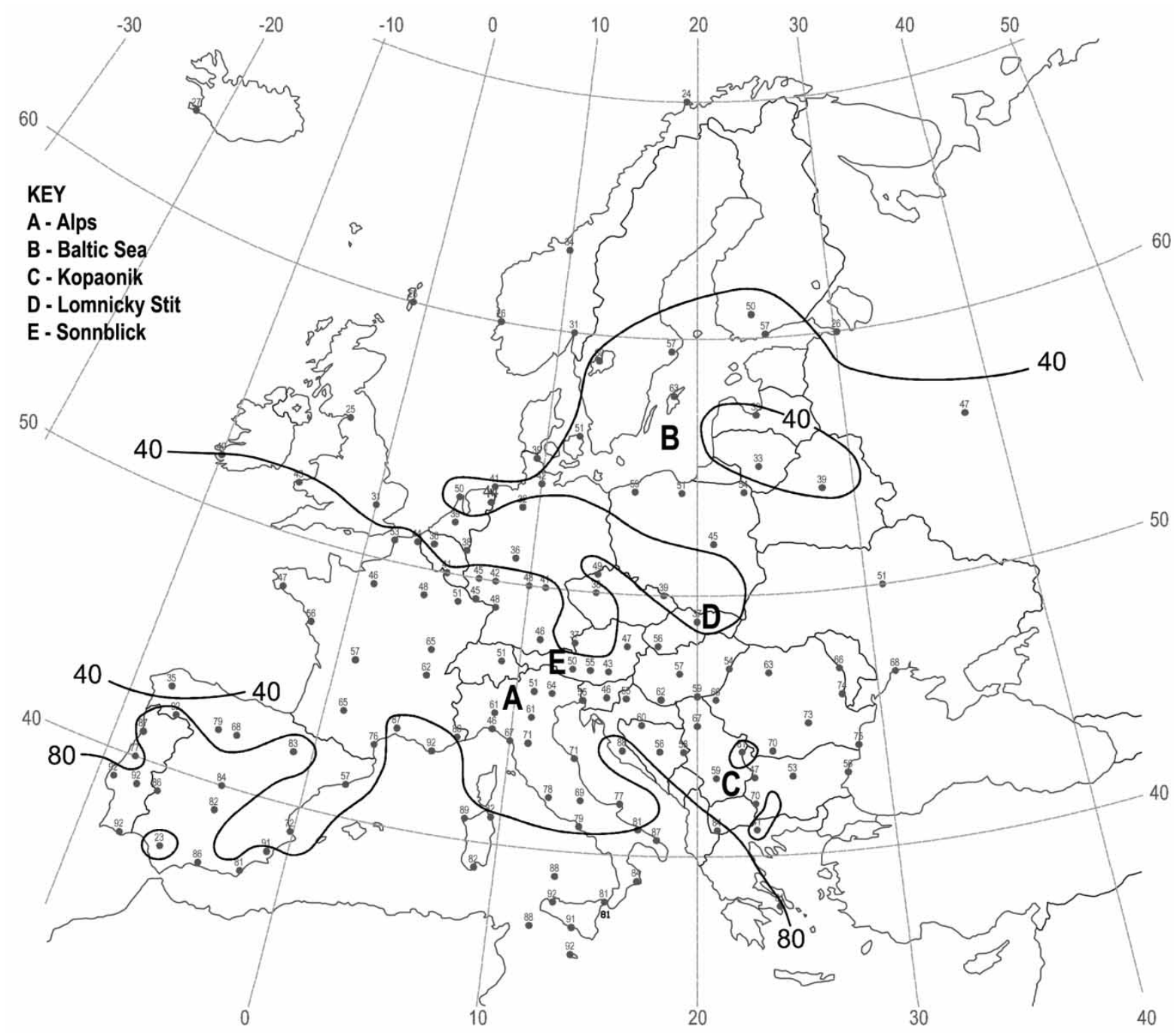

Fig. 13 Contour maps of the number of days in a year for which the temperature of water in the storage tank reaches or exceeds $55^{\circ} \mathrm{C}$ for Europe

the wider data arrays distribution along the solar fraction axis. For higher values of solar fractions and specific number of days, there was less spread of data points.

\section{CONCLUSION}

Correlations have been established for the number of days a specified hot water demand temperature can

Table 4 Coefficients for the determination of the maximum and minimum threshold total solar radiation on horizontal surface as functions of demand temperature and period of year

\begin{tabular}{|c|c|c|c|c|c|c|c|c|c|}
\hline \multirow[b]{2}{*}{ Period of year } & \multirow{2}{*}{$\begin{array}{l}\text { Demand } \\
\text { temperature }\left({ }^{\circ} \mathrm{C}\right)\end{array}$} & \multicolumn{4}{|c|}{ Coefficients for $I_{0}$} & \multicolumn{4}{|c|}{ Coefficients for $I_{\max }$} \\
\hline & & $a\left(\mathrm{GJ} \mathrm{m}^{-2}\right)$ & $\Delta(\%)$ & $b\left(\mathrm{GJ} \mathrm{m} \mathrm{m}^{-2}\right)$ & $\Delta(\%)$ & $c\left(\mathrm{GJ} \mathrm{m} \mathrm{m}^{-2}\right)$ & $\Delta(\%)$ & $d\left(\mathrm{GJ} \mathrm{m} \mathrm{m}^{-2}\right)$ & $\Delta(\%)$ \\
\hline \multirow{2}{*}{ Whole year } & 45 & 1.09 & 2.3 & 1.01 & 2.97 & 5.36 & 3.42 & 1.08 & 3.7 \\
\hline & 55 & 1.3 & 1.93 & 1.23 & 4.07 & 5.79 & 0.37 & 1.38 & 0.72 \\
\hline \multirow{3}{*}{ April to September } & 37 & 0.54 & 26.67 & 1.4 & 21.43 & 3.6 & 1 & 0.23 & 8.7 \\
\hline & 45 & 0.97 & 8.15 & 1.01 & 9.9 & 3.53 & 1.33 & 0.43 & 8.7 \\
\hline & 55 & 1.22 & 3.82 & 1.18 & 8.47 & 3.53 & 0.92 & 0.63 & 3.17 \\
\hline \multirow[t]{3}{*}{ June to August } & 37 & 0.35 & 18.75 & 1.2 & 16.67 & 1.9 & 0.38 & 0.18 & 5.56 \\
\hline & 45 & 0.54 & 6 & 1.01 & 7.92 & 1.92 & 1.12 & 0.32 & 6.25 \\
\hline & 55 & 0.65 & 7.78 & 1.2 & 16.67 & 1.94 & 1.48 & 0.5 & 8 \\
\hline
\end{tabular}

$\Delta(\%)$ is the maximum error in each case. 


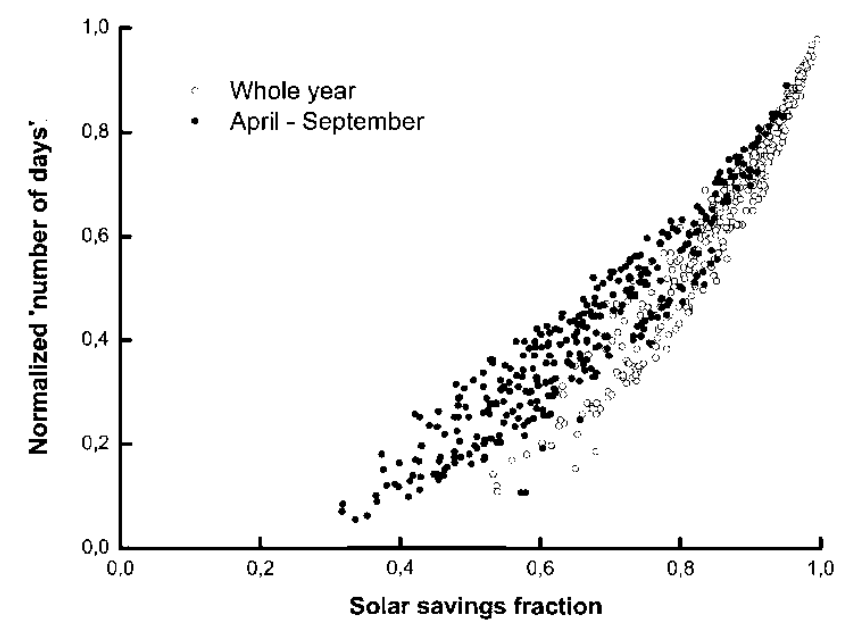

Fig. 14 A comparison of the number of days for which the temperature of water in the storage tank reaches or exceeds specified demand temperatures and solar fractions for Europe for the whole year and for the period April to September be satisfied by a SWH without the use of auxiliary heating for 147 European locations for a whole and part year periods. The accuracy in determining the number of days is in the range 10-30 per cent; the error is the smallest for higher values of total insolation. An example of using the correlation to estimate the performance of a SWH for any location in Europe is provided in Appendix 2 for solar collectors with areas and specifications corresponding to those used in this study. If the latter is not the case, the 'number of days' and the terms $I_{0}$ and $I_{\max }$ may be calculated using equations (1) and (2), respectively. The coefficients $a, b, c$, and $d$ may be obtained from Table 4 for the period under consideration.

Figures 11 to 13 show that with increasing altitude, particularly in the Alps, contours deviate with greater irregularity from a broad alignment with latitude. The effect of higher summer ambient temperatures associated with the prevailing continental climate in northern Europe can also be seen in the form of the contours in the region of the southern Baltic Sea.

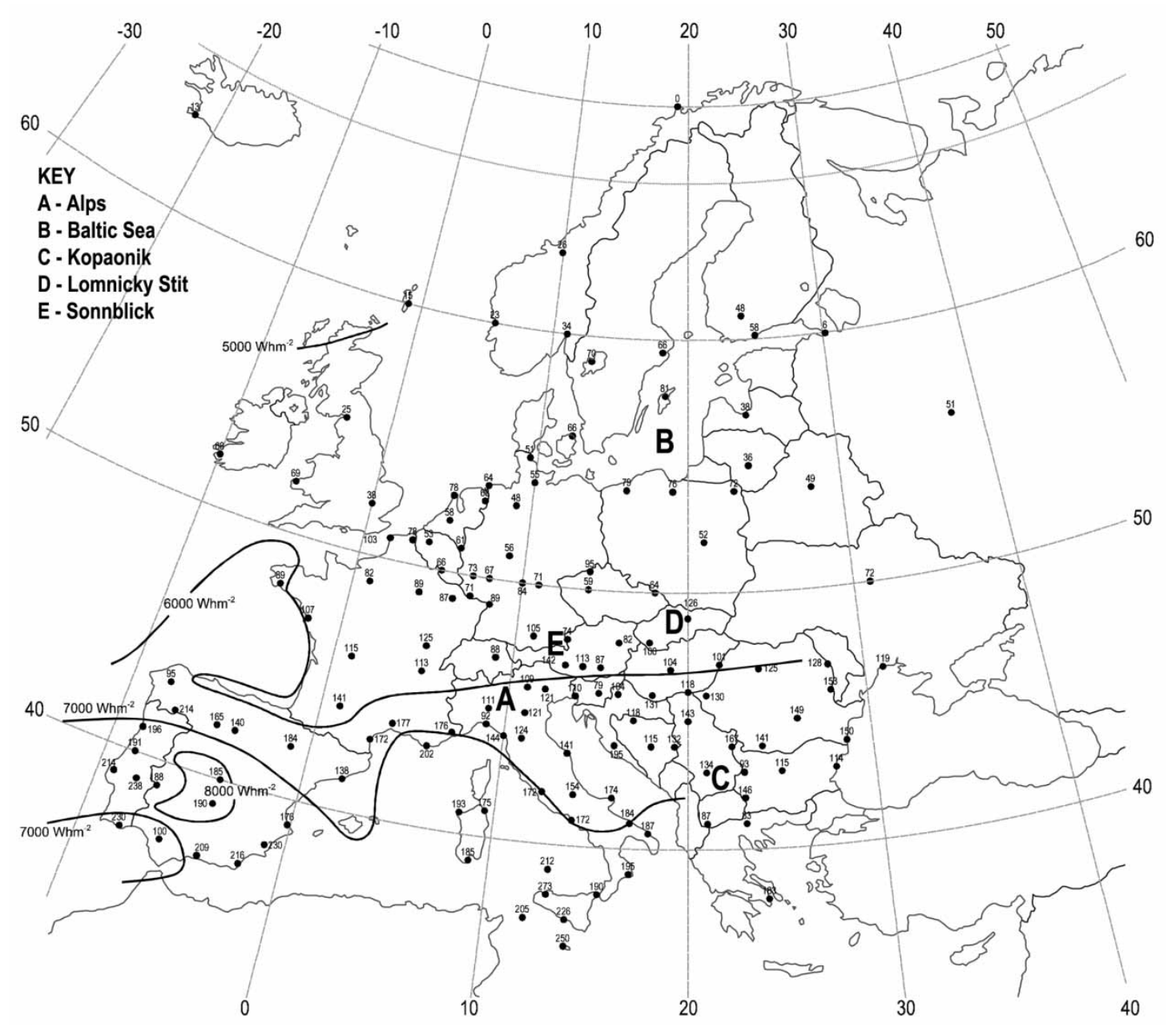

Fig. 15 Mean monthly cumulative daily global insolation on a horizontal plane for July (based on 1985 to 2000 Meteosat data) 
(As solar energy collection is more limited in winter, the cold winters also associated with a continental climate have less effect.) Higher demand temperatures entail a larger difference between SWH and ambient temperatures and thus increased system heat loss. As they influence ambient temperature, both altitude and continental climate effects on heat loss become more pronounced at higher demand temperatures. In south-west Spain, maritime cloud cover leads to lower insolation in south-west Spain as shown in Fig. 15 in the crucial summer period.

In colder part of year, there are more days when water is not heated to the specified demand temperatures, therefore in Fig. 14, whole year date points sit below April-to-September data. The solar fraction threshold below which the normalized number of days is zero is 0.3 for April to September and 0.5 for the whole year. (These values for the whole of Europe are very similar to those for London and Northern Ireland [5] conditions.) It is thus not possible for the particular SWH considered to provide hot water at a specified demand temperature of $37^{\circ} \mathrm{C}$ or above throughout the year without the use of auxiliary heating at any location in Europe.

Taken with cost and product quality information, the production of contour maps as described in this paper to show the geographic variation of the performance of different SWH would aid both system selection for designers and the definition of appropriate markets for manufacturers.

\section{REFERENCES}

1 Morrison, G. L. Solar water heating in solar energy: the state of the art (Ed. J. Gordon) 2001 (James and James Publishers Ltd, London, UK).

2 Urbschat, C. Sunrise 2002: die europaischen markte fur solarthermie und photovoltaik, 2002 (Eclareon Gmbh, Berlin, Germany).

3 Reddy, T. A. The design and sizing of active solar thermal systems, 1987 (Clarendon Press, Oxford, UK).

4 Bourges, B. European simplified methods for active solar system design, 1991 (Kluwer Academic Publishers, Dordtrect, The Netherlands).

5 Yohanis, Y. G., Popel, O., Frid, S. E., and Norton, B. Analysis of the annual number of days for which solar heated water can be provided above a specified demand temperature. Sol. Energy, 2005, in press.

6 Beckman, W. A., Klein, S. A., and Duffie, J. A. Solar heating design by the f-chart method, 1977 (WileyInterscience, New York).

7 Duffie, J. A. and Beckman, W. A. Solar engineering of thermal processes, 1980 (Wiley, New York).

8 Klein, S. A., Duffie, J. A., Mitchell, J. C., Kummer, J. P., Beckmann, W. A., Duffie, N. A., Braun, J. E., Urban, R. E., Thornton, J. W., Mitchell, J. W., Freeman, T. L., Evans, B. L., and Fiksel, A. TRNSYS 15, a transient system simulation program. User's manual (version
15), 2000 (Solar Energy Laboratory, University of Wisconsin-Madison).

9 Anonymous. RETScreen international (RETScreen), 2000 (CANMET Energy Diversification Research Laboratory (CEDRL), Canada), available from http:// retscreen.gc.ca.

10 Weiss, W. Come in from the cold? The solar thermal market in Europe. Renew. Energy World, 2002 5(4), 91-97.

11 Weiss, W. and Faninger, G. Solar thermal collector market in IEA member countries. Report of IEA Solar Heating and Cooling Programme, 2002.

12 Zaidel, A. N. Errors in measurement of physical values, 1974 (Science Publishers, Leningrad, Russia) (in Russian).

\section{APPENDIX 1}

\section{Notation}

\begin{tabular}{|c|c|}
\hline$a, b, c$ & coefficient \\
\hline$A_{\mathrm{sc}}$ & solar collector surface area $\left(\mathrm{m}^{2}\right)$ \\
\hline$f$ & solar fraction \\
\hline$F^{\prime \prime}$ & solar collector flow factor \\
\hline$F_{\mathrm{R}}$ & solar collector heat removal factor \\
\hline$I$ & 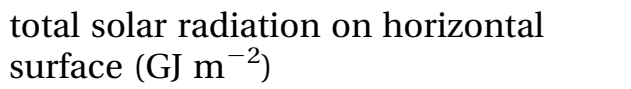 \\
\hline$I_{\max }$ & $\begin{array}{l}\text { maximum threshold total solar radiation } \\
\text { on horizontal surface }\left(\mathrm{GJ} \mathrm{m} \mathrm{m}^{-2}\right)\end{array}$ \\
\hline$I_{0}$ & $\begin{array}{l}\text { minimum threshold total solar } \\
\text { radiation on horizontal surface } \\
\left(\mathrm{GJ} \mathrm{m}^{-2}\right)\end{array}$ \\
\hline$N$ & $\begin{array}{l}\text { number of days a specified hot water } \\
\text { demand temperature is met solely by } \\
\text { solar energy }\end{array}$ \\
\hline$N_{\max }$ & $\begin{array}{l}\text { maximum threshold number of } \\
\text { days a specified hot water demand } \\
\text { temperature is met solely by solar } \\
\text { energy }\end{array}$ \\
\hline$N_{U_{\mathrm{L}}}$ & $\begin{array}{l}\text { for a particular overall heat loss } \\
\text { coefficient, the number of days } \\
\text { a specified hot water demand } \\
\text { temperature is met solely by } \\
\text { solar energy }\end{array}$ \\
\hline$Q_{\text {aux }}$ & auxiliary heating requirement $(\mathrm{J})$ \\
\hline$Q_{\mathrm{T}}$ & $\begin{array}{l}\text { useful heat produced by solar energy } \\
\text { during the lifetime of SWH }(\mathrm{J})\end{array}$ \\
\hline$Q_{\text {tot }}$ & $\begin{array}{l}\text { total energy required to heat the supply } \\
\text { water to the demand temperature }(\mathrm{J})\end{array}$ \\
\hline$t^{*}$ & $\begin{array}{l}\text { specified demand water temperature in } \\
\text { storage tank }\left({ }^{\circ} \mathrm{C}\right)\end{array}$ \\
\hline$U_{\mathrm{L}}$ & 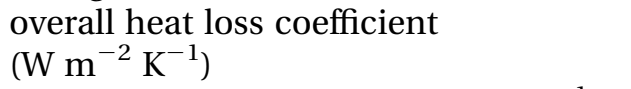 \\
\hline$V_{\text {day }}$ & daily hot water requirement $\left(\mathrm{lday}^{-1}\right)$ \\
\hline$V_{\mathrm{st}}$ & storage volume (l) \\
\hline$\tau \alpha$ & optical coefficient \\
\hline
\end{tabular}




\section{APPENDIX 2}

As an example of the estimation of the performance of $\mathrm{SWH}$ using the correlation developed earlier, a SWH at Kew near London is considered. The total insolation on a horizontal surface for whole year, half-year, and summer are 3.23, 2.51, and $1.43 \mathrm{GJ} \mathrm{m}^{-2}$, respectively [9].

To estimate the solar collector area $\left(A_{\mathrm{SC}}\right)$ for a half-year operating period, the following procedure is adopted. For a daily hot water requirement $V_{\text {day }}=100 \mathrm{l}$, using Fig. 5, determine the "number of days' $(N)$ for a specified temperature $\left(t^{*}\right)$ for $2.51 \mathrm{GJ} \mathrm{m}^{-2}$ total insolation on a horizontal surface for half-year period operation for collector areas $\left(A_{\mathrm{sc}}\right)$ of 1,2 , and $3 \mathrm{~m}^{2}$ :

(a) for $A_{\mathrm{sc}}=1 \mathrm{~m}^{2}$ and $t^{*} \geqslant 37^{\circ} \mathrm{C}, N=50$ days;

(b) for $A_{\mathrm{sc}}=1 \mathrm{~m}^{2}$ and $t^{*} \geqslant 45^{\circ} \mathrm{C}, N=5$ days;

(c) for $A_{\mathrm{sc}}=1 \mathrm{~m}^{2}$ and $t^{*} \geqslant 55^{\circ} \mathrm{C}, N=0$ days.

If the 'number of days' obtained using a collector area of $1 \mathrm{~m}^{2}$ does not meet the requirement, then
Fig. 6 is used to determine $N$ for a collector area of $2 \mathrm{~m}^{2}$. As earlier, $N$ is determined as follows:

(a) for $A_{\mathrm{sc}}=2 \mathrm{~m}^{2}$ and $t^{*} \geqslant 37^{\circ} \mathrm{C}, N=100$ days;

(b) for $A_{\mathrm{sc}}=2 \mathrm{~m}^{2}$ and $t^{*} \geqslant 45^{\circ} \mathrm{C}, N=70$ days;

(c) for $A_{\mathrm{sc}}=2 \mathrm{~m}^{2}$ and $t^{*} \geqslant 55^{\circ} \mathrm{C}, N=35$ days.

This procedure is repeated for a collector area of $3 \mathrm{~m}^{2}$ as shown subsequently:

(a) for $A_{\mathrm{sc}}=3 \mathrm{~m}^{2}$ and $t^{*} \geqslant 37^{\circ} \mathrm{C}, N=130$ days;

(b) for $A_{\mathrm{sc}}=3 \mathrm{~m}^{2}$ and $t^{*} \geqslant 45^{\circ} \mathrm{C}, N=85$ days;

(c) for $A_{\mathrm{sc}}=3 \mathrm{~m}^{2}$ and $t^{*} \geqslant 55^{\circ} \mathrm{C}, N=65$ days.

This is based on daily consumption of $100 \mathrm{l}$ and a storage volume of $100 \mathrm{l}$ as well. If the required daily consumption is different, say 3001 , a scaling method can be applied. The storage volume as earlier will be taken to be the same as the daily requirement, i.e. 300 l. The collector area $\left(A_{\mathrm{sc}}\right)$ is scaled by the ratio of daily requirement to storage, i.e. $A_{\mathrm{sc}}\left(V_{\mathrm{day}} / V_{\mathrm{st}}\right)$. In this case, the scaling factor will be equal to 3 ; this means that the new collector area will be three times larger. All the earlier calculations are based on the base case as given in Table 2 . 